\title{
Hypomagnesemia as First Clinical Manifestation of ADTKD-HNF1B: A Case Series and Literature Review
}

\author{
Cas I. van der Made ${ }^{a}$ Ewout J. Hoorn ${ }^{b}$ Renaud de la Faille ${ }^{d}$ \\ Huseyin Karaaslan ${ }^{\mathrm{e}}$ Nine V.A.M. Knoers ${ }^{\mathrm{c}}$ Joost G.J. Hoenderop ${ }^{\mathrm{a}}$ \\ Rosa Vargas Poussou ${ }^{f}$ Jeroen H.F. de Baaij ${ }^{\mathrm{a}}$
}

${ }^{a}$ Department of Physiology, Radboud Institute for Molecular Life Sciences, Radboud University Medical Center, Nijmegen, ${ }^{\mathrm{b}}$ Department of Internal Medicine, Erasmus Medical Center, Rotterdam, and ' Department of Medical Genetics, University Medical Center Utrecht, Utrecht, The Netherlands; ${ }^{\mathrm{d} C e n t r e ~ H o s p i t a l i e r ~ U n i v e r s i t a i r e ~ d e ~}$ Bordeaux, Service de Néphrologie Transplantation Dialyse, Bordeaux, ${ }^{e}$ Hôpital Medipole, Service de Néphrologie, Bourgoin Jallieu, and f Département de Génétique, Hôpital Européen Georges Pompidou, Paris, France

\section{Key Words}

HNF1B · Hypomagnesemia $\cdot$ RCAD $\cdot$ MODY5 $\cdot$ CAKUT ·

ADTKD-HNF1B

\section{Abstract}

Background: Autosomal dominant tubulointerstitial kidney disease subtype HNF1B (ADTKD-HNF1B) is caused by a mutation in hepatocyte nuclear factor 1 homeobox beta (HNF1B). Although 50-60\% of ADTKD-HNF1B patients develop hypomagnesemia, HNF1B mutations are mainly identified in patients with structural kidney defects or diabetes. Cases: The current case series describes 3 patients in whom hypomagnesemia proved to be the first clinical manifestation of ADTKD-HNF1B. All patients presented with hypomagnesemia with a high fractional excretion of $\mathrm{Mg}^{2+}$ and hypocalciuria. Exome sequencing performed for analysis of known and candidate hypomagnesaemia genes and subsequent multiplex ligation-dependent probe amplification analysis revealed a large deletion at the chromosome $17 q 12$. Follow-up analysis showed increased blood glucose concentrations in all 3 patients and high hemoglobin A1c levels in 2 out of 3 patients, indicating diabetes mellitus. Although all patients suffered from mild renal insufficiency, only 1 of the 3 patients was shown to have renal cysts on CT. Conclusion: The prevalence of HNF1B mutations and the relative contribution of hypomagnesemia to its symptoms are underestimated. Therefore, patients with primary renal magnesium wasting should be tested for $H N F 1 B$ mutations to ensure early detection and optimal management of ADTKD-HNF1B.

C 2015 S. Karger AG, Basel

\section{Introduction}

Autosomal dominant tubulointerstitial kidney disease subtype HNF1B (ADTKD-HNF1B; MIM \#137920) comprises non-diabetic renal disease and maturity-onset diabetes of the young (MODY5), and it is caused by mutations in hepatocyte nuclear factor 1 homeobox beta $(H N F 1 B)[1]$. HNF1B is a transcription factor that regulates genes that are cardinal to the development of the kidney, liver, pancreas and genital tract, and its impairment consequently leads to structural and functional anomalies of these organs [1-3]. Mutations in HNF1B are the most frequent monogenetic cause of congenital

\section{KARGER 125}

(c) 2015 S. Karger AG, Base

0250-8095/15/0421-0085\$39.50/0

E-Mail karger@karger.com

www.karger.com/ajn
Jeroen H.F. de Baaij

Department of Physiology, Radboud University Medical Center PO Box 9101

NL-6500HB Nijmegen (The Netherlands)

E-Mail jeroen.debaaij@ radboudumc.nl 


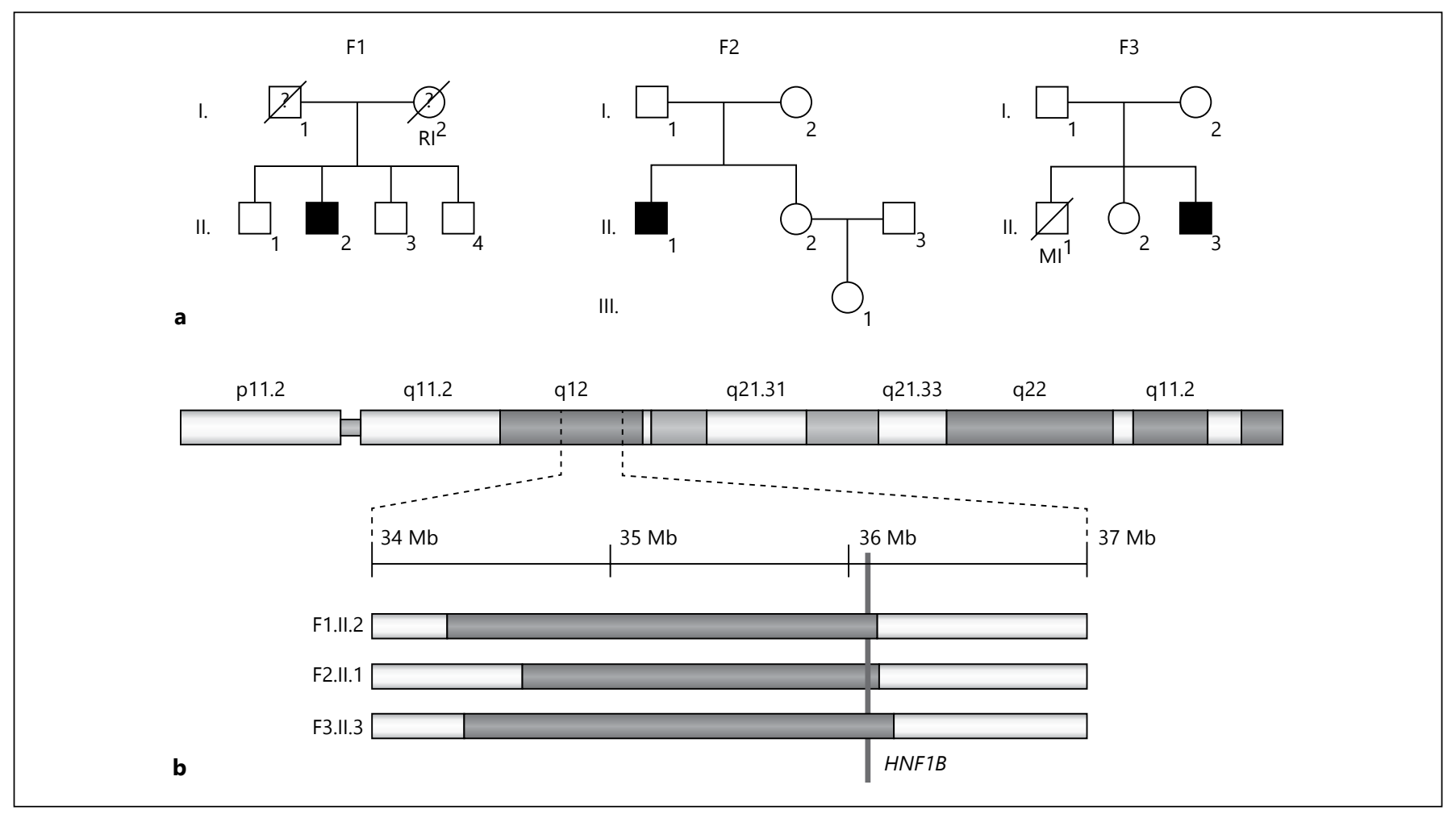

Fig. 1. Familial background and overview of $H N F 1 B$ deletions. a Pedigrees of families F1-F3. Filled symbols represent the affected index patients. b Localization and size of the HNF1B deletions on locus q12, chromosome 17, are shown in black. The $H N F 1 B$ gene is situated in the highlighted area. RI = Renal insufficiency; $\mathrm{MI}=$ myocardial infarction. anomalies of the kidneys and urinary tract (CAKUT) and are observed in 10-30\% of CAKUT patients in the prenatal period [4]. Importantly, diagnosing $H N F 1 B$ mutations in the clinic is difficult due to high phenotypic variability between patients, incomplete penetrance, complicated detection of heterozygous gene deletions by sequencing and a high de novo mutation rate [2].

Initial reports show that hypomagnesemia is encountered in $\pm 50 \%$ of ADTKD-HNF1B patients and has a high specificity for HNF1B status [1]. Defects in HNF1B primarily affect renal $\mathrm{Mg}^{2+}$ handling in the distal convoluted tubule, where transcellular $\mathrm{Mg}^{2+}$ transport determines the final urinary $\mathrm{Mg}^{2+}$ excretion [5]. In the distal convoluted tubule, $\mathrm{Mg}^{2+}$ reabsorption is achieved via transient receptor potential melastatin type 6 (TRPM6) $\mathrm{Mg}^{2+}$ channels and is dependent upon the voltage gradient set by the $\mathrm{Na}^{+}-\mathrm{K}^{+}$-ATPase. Indeed, patients with mutations in FXYD2, which encodes the $\gamma$-subunit of the $\mathrm{Na}^{+}-\mathrm{K}^{+}$ATPase, suffer from hypomagnesemia and renal $\mathrm{Mg}^{2+}$ wasting [6]. In addition, it has been shown that HNF1B, together with its dimerization factor PCBD1, regulates the transcription of FXYD2, which explains why HNF1B and $P C B D 1$ mutations result in renal $\mathrm{Mg}^{2+}$ wasting $[3,7]$. Nevertheless, mutations or deletions of $H N F 1 B$ are infrequently considered in patients with hypomagnesemia without additional symptoms, such as diabetes or kidney abnormalities.

Here, we aim to establish hypomagnesemia as an important indicator to test for $H N F 1 B$ mutations. We present 3 patients in whom hypomagnesemia was the first clinical manifestation of ADTKD-HNF1B and provide an overview of the current literature on hypomagnesemia in ADTKD-HNF1B patients.

\section{Case Report}

We report 3 patients diagnosed with ADTKD-HNF1B who presented with marked unexplained hypomagnesemia.

Patient 1 (fig. 1a, F1.II.1), a 44-year-old male of Turkish origin was found to have pronounced hypomagnesemia $(0.28 \mathrm{mmol} / \mathrm{l})$ and mild renal insufficiency (RI) during examination of his kidney stones (table 1). Urinary analysis indicated high fractional excretion of magnesium (table 1). Ultrasound showed nephrolithiasis without structural kidney abnormalities. Patient DNA was sent in 
Table 1. Clinical characteristics of ADTKD-HNF1B patients

\begin{tabular}{|c|c|c|c|c|}
\hline Parameter & $\begin{array}{l}\text { Patient } 1 \\
(\text { male, } \mathrm{n}=44)\end{array}$ & $\begin{array}{l}\text { Patient } 2 \\
(\text { male, } \mathrm{n}=42)\end{array}$ & $\begin{array}{l}\text { Patient } 3 \\
\text { (male, } n=33 \text { ) }\end{array}$ & $\begin{array}{l}\text { Reference } \\
\text { values }\end{array}$ \\
\hline \multicolumn{5}{|l|}{ Serum indices } \\
\hline $\mathrm{K}^{+}, \mathrm{mEq} / \mathrm{l}$ & 3.7 & 3.9 & 3.9 & $3.5-5.0$ \\
\hline $\mathrm{Mg}^{2+}, \mathrm{mEq} / \mathrm{l}$ & $0.56^{*}$ & $0.84^{*}$ & $0.86^{*}$ & $1.3-2.1$ \\
\hline $\mathrm{Ca}^{2+}, \mathrm{mg} / \mathrm{dl}$ & 8.8 & 9.4 & 10.0 & $8.2-10.2$ \\
\hline Creatinine, $\mathrm{mg} / \mathrm{dl}$ & 0.96 & 1.02 & $1.44^{*}$ & $0.6-1.2$ \\
\hline $\mathrm{GFR}, \mathrm{ml} / \mathrm{min} / 1.73 \mathrm{~m}^{2}$ & $63^{*}$ & $81^{*}$ & $57^{*}$ & $>90$ \\
\hline Uric acid, mg/dl & - & 7.95 & $8.24^{*}$ & $4.0-8.0$ \\
\hline Fasting glucose, $\mathrm{mg} / \mathrm{dl}$ & $400^{*}$ & $189^{*}$ & $149 *$ & $70-110$ \\
\hline HbA1c, $\%$ of total & $11.9^{*}$ & $9.0^{*}$ & 6.8 & $4.0-7.0$ \\
\hline \multicolumn{5}{|l|}{ Urinary indices } \\
\hline
\end{tabular}

The fractional excretion of $\mathrm{Mg}^{2+}(\mathrm{FEMg})$ was calculated using the following formula: $\mathrm{FEMg}(\%)=\left(\mathrm{U}_{\mathrm{Mg}} \times \mathrm{P}_{\mathrm{Cr}}\right) /\left(\left(0.7 \times \mathrm{P}_{\mathrm{Mg}}\right) \times \mathrm{U}_{\mathrm{Cr}}\right) \times$ 100. GFR was derived from the Modification of Diet in Renal Disease formula.

Conversion factors for units: serum $\mathrm{Mg}^{2+}$ in $\mathrm{mEq} / \mathrm{l}$ to $\mathrm{mmol} / \mathrm{l}, \times 0.5$; serum $\mathrm{Ca}^{2+}$ in $\mathrm{mg} / \mathrm{dl}$ to $\mathrm{mmol} / 1, \times 0.25 ;$ serum $\mathrm{PO}_{4}{ }^{3-}$ in $\mathrm{mg} / \mathrm{dl}^{2}$ to $\mathrm{mmol} / \mathrm{l}, \times 0.323$; serum creatinine in $\mathrm{mg} / \mathrm{dl}$ to $\mu \mathrm{mol} / \mathrm{l}, \times 88.4$; serum uric acid $\mathrm{mg} / \mathrm{dl}$ to $\mathrm{mmol} / \mathrm{l}, \times 59.485$; serum fasting glucose in $\mathrm{mg} / \mathrm{dl}$ to $\mathrm{mmol} / \mathrm{l}, \times 0.0555$; HbAlc in $\%$ of total to $\mathrm{mmol} / \mathrm{mol}, \times 10.9-23.5$. ${ }^{*}$ Abnormal value.

for exome sequencing (informed consent was given for this procedure), but despite good coverage ( $>99 \%)$, no mutations were identified in the genes known to cause hypomagnesemia. Copy number variation analysis on the exome sequencing data revealed a $17 \mathrm{q} 12$ deletion (fig. 1b, Chr17:34,326,941-36,152,187, hg19), which includes the $H N F 1 B$ gene. Heterozygous $H N F 1 B$ deletion was confirmed by multiplex ligation-dependent probe amplification (MLPA). The deletion of $H N F 1 B$ was not encountered in the 3 unaffected brothers (fig. 1a, F1.II.1, F1.II.3, F1.II.4) of the patient. Additional testing in the index patient (2 years later) showed diabetes mellitus, evidenced by elevated fasting glucose and glycated hemoglobin A1c (HbA1c) levels (table 1). CT confirmed the absence of kidney structural abnormalities (table 1).

Patient 2 (fig. 1a, F2.II.2), a 42-year-old French male, was referred to a nephrologist for diagnostic evaluation of symptomatic hypomagnesemia $(0.42 \mathrm{mmol} / \mathrm{l})$, discovered during the work-up of his chondrocalcinosis. Additionally, hypocalciuria, hyperglycemia, high $\mathrm{HbAlc}$ and hyperuricemia were observed, with renal magnesium wasting, indicating renal etiology (table 1). Ultrasound and CT of the kidneys excluded nephrolithiasis, nephrocalcinosis, cysts or other structural abnormalities. Exome sequencing yielded a heterozygous TRPM6 variant (c.5517del, pLys1839fs). Genetic analysis of the relatives showed the presence of this TRPM6 variant in the unaffected father (fig. 1a, F2.I.1) and sister (fig. 1a, F2.II.2). Given the recessive nature of TRPM6-associated disease, the TRPM6 p.Lys1839fs variant was ruled out as the cause of hypomagnesemia. Successive HNF1B MLPA testing in the patient confirmed a heterozygous HNF1B deletion (fig. 1b, Chr17:34,619,998-36,152,274, hg19).

Patient 3 (fig. 1a, F3.II.3), a 32-year-old Dutch male, was referred for further analysis of unexplained hypomagnesemia $(0.43$ $\mathrm{mmol} / \mathrm{l})$ with renal magnesium wasting (table 1$)$. Hypomagnese$\mathrm{mia}(0.21 \mathrm{mmol} / \mathrm{l})$ was discovered by chance during intensive care admission for a pulmonary embolism in 2004 . In addition, the patient had hypocalciuria and a mild RI without proteinuria (table 1). Ultrasound showed 2 cysts in the right kidney $(1.5$ and $1.3 \mathrm{~cm})$ and 1 cyst in the left kidney $(1 \mathrm{~cm})$. The patient's history included failure to thrive as a child, epilepsy and mental retardation. Copy number variation analysis of the exome sequencing data yielded a 17q12 deletion (fig. 1b, Chr17:34,431,920-36,214,800, hg19) that included HNF1B as confirmed by MLPA. During follow-up, the patient developed diabetes mellitus for which insulin was started.

\section{Discussion}

This case series reports 3 patients with $H N F 1 B$ mutations in whom hypomagnesemia was the initial and predominant symptom of the disease. In contrast to the suggestion that hypomagnesemia is a late manifestation of ADTKD-HNF1B, our findings indicate that impairment of renal $\mathrm{Mg}^{2+}$ handling can arise when no impairment of kidney function or diabetes mellitus is present [8]. Timely detection of $H N F 1 B$ mutations will enable better disease management, which includes treatment of MODY5, electrolyte disturbances, genetic counseling, gynecological examination for uterine abnormalities and follow-up 
Table 2. Literature overview of hypomagnesemia in ADTKD-HNF1B patients

\begin{tabular}{|c|c|c|c|}
\hline $\begin{array}{l}\text { Research } \\
\text { article }\end{array}$ & Patient inclusion criteria & $\begin{array}{l}\text { Adults with } \\
\text { hypomagnesemia } \\
\text { (percentage) }\end{array}$ & $\begin{array}{l}\text { Children with } \\
\text { hypomagnesemia } \\
\text { (percentage) }\end{array}$ \\
\hline $\begin{array}{l}\text { Heidet } \\
\text { et al., } 2010 \text { [11] }\end{array}$ & $\begin{array}{l}\text { Unrelated subjects with one of the following features: } \\
\text { hyperechogenic kidneys with a size } \leq 3 \text { SD; multicystic kidney disease; } \\
\text { renal agenesis; renal hypoplasia; cystic dysplasia; or hyperuricemic } \\
\text { tubulointerstitial nephropathy not associated with a UMOD mutation }\end{array}$ & Not quantified & Not quantified \\
\hline $\begin{array}{l}\text { Faguer } \\
\text { et al., } 2014 \text { [2] }\end{array}$ & $\begin{array}{l}\text { The cohort was comprised of } 433 \text { consecutive patients tested for } \\
H N F 1 B \text { between January } 2008 \text { and June } 2011 \text { in Toulouse. Only } \\
\text { probands presenting with features suggestive of } H N F 1 B \text {-related disease } \\
\text { were included, whereas relatives tested for family screening were } \\
\text { excluded }\end{array}$ & $3 / 17(18)$ & $0 / 39(0)$ \\
\hline
\end{tabular}

It should be noted that in many cohorts the patients were not included based on predefined selection criteria, but were selected for HNF1B testing by physicians for various reasons.

of anomalies that might manifest later in the course of the disease [8-10].

Since the first reported association of hypomagnesemia with $H N F 1 B$ mutations in 2009 [1], several articles have found that hypomagnesemia is frequently encountered in patients with ADTKD-HNF1B $[2,8,11,12]$. In table 2, all studies with ADTKD-HNF1B cohorts reporting hypomagnesaemia are listed. This overview of the occurrence of hypomagnesemia in patients with $H N F 1 B$ mutations demonstrates the discrepancy between studies systematically assessing $\mathrm{Mg}^{2+}$ status and studies based on retrospective patient file analysis. In studies that have 
systematically tested serum $\mathrm{Mg}^{2+}$ concentrations, the prevalence of hypomagnesemia in ADTKD-HNF1B patients ranges between 25 and $75 \%$, depending on the cohort $[1,8,12]$. Pediatric cohorts tend to show a slightly lower prevalence of hypomagnesemia (table 2). Interestingly, studies in which hypomagnesemia is part of retrospective analysis report prevalence between 3 and $10 \%$. This difference may be explained by the use of the entire cohort as a denominator in these studies, whereas $\mathrm{Mg}^{2+}$ determinations are not part of routine measurements and were not performed in many cases.

In general, the prevalence of hypomagnesemia and other electrolyte disorders in ADTKD-HNF1B may be higher than previously reported. Epidemiological data regarding the clinical characteristics of ADTKD-HNF1B are predominantly derived from pre-selected CAKUT cohorts [2, $8,13,14]$. Hypomagnesemia may be an important predictor of HNF1B mutations, which are accountable for approximately $10 \%$ of kidney abnormalities in all CAKUT patients $[8,11]$. Systematic testing of $\mathrm{Mg}^{2+}$ status is still not routinely performed in CAKUT cohorts. Moreover, no large-scale data are available of ADTKD-HNF1B patients who were initially diagnosed with other symptoms, like diabetes mellitus. Consequently, this selection bias might overestimate the occurrence of structural kidney defects and underestimate the associated electrolyte disorders, including hypomagnesemia. Therefore, current clinical guidelines to select patients for genetic HNF1B testing may be largely dependent on kidney abnormalities, and clinicians may be reluctant to test patients with isolated hypomagnesemia for $H N F 1 B$ deletions and mutations.

Recently, a $H N F 1 B$ score has been developed as a diagnostic tool to select patients for HNF1B analysis [2]. However, only 1 patient of all the cases presented in this paper would have met the threshold criteria of the $H N F 1 B$ score, mainly due to the absence of structural kidney abnormalities in the other 2 patients [2]. The ADTKD-HNF1B cases, from which the HNF1B score has been derived, were selected until 2010, which is shortly after hypomagnesemia was first reported in these patients. Additionally, the score is based on retrospective analysis. In many of the cohorts that were implemented in the HNF1B score $\mathrm{Mg}^{2+}$ status was not assessed, and consequently, hypomagnesemia was found in only $4 \%$ of the patients [2]. As a result, hypomagnesemia is underappreciated as an indicator for $H N F 1 B$ mutations in the HNF1B score, as has been noted by follow-up reports [8]. Moreover, HNF1B deletions are often part of a 17q12 microdeletion syndrome, as in our patients, $\mathrm{Mg}^{2+}$ status was only measured in a paucity of patients with 17q12 deletions [15-17]. These findings em- phasize the lack of regular $\mathrm{Mg}^{2+}$ measurements, even in patients with $H N F 1 B$ deletions. Additionally, hypomagnesemia patients are not routinely tested for large deletions, and these deletions are easily missed by sequencing.

In this case series, ADTKD-HNF1B patients were diagnosed after evaluation of their isolated hypomagnesemia, without diabetes mellitus or structural kidney abnormalities. As illustrated by these cases, $H N F 1 B$ deletions are often not identified by sequencing, but become apparent only after successive analyses such as MLPA. Mutations in $H N F 1 B$ are among the most common genetic causes of hypomagnesemia. Nevertheless, HNF1B mutations are generally only diagnosed when patients develop diabetes mellitus or when structural kidney defects are identified. Therefore, we propose that patients with primary hypomagnesemia should be tested for HNF1B mutations, even in the absence of renal cysts or diabetes, to diagnose ADTKD-HNF1B at an early stage and enable optimal management of the disease. Moreover, $\mathrm{Mg}^{2+}$ concentrations should be systematically assessed in CAKUT patients, since it strongly predicts $H N F 1 B$ mutations. Earlier detection of $H N F 1 B$ mutations in patients with primary hypomagnesemia will result in a better management of the disease.

\section{Acknowledgments}

This work was supported by grants from the Netherlands Organization for Scientific Research (VICI 016.130.668) and the EURenOmics project from the European Union seventh Framework Programme (FP7/2007-2013, agreement nu 305608). Jeroen de Baaij is supported by grants from NWO (Rubicon 825.14.021) and the Dutch Kidney Foundation (Kolff 14OKG17).

\section{Disclosure Statement}

The authors have no conflict of interest to declare.

\section{References}

1 Adalat S, Woolf AS, Johnstone KA, Wirsing A, Harries LW, Long DA, Hennekam RC, Ledermann SE, Rees L, van't Hoff W, Marks SD, Trompeter RS, Tullus K, Winyard PJ, Cansick J, Mushtaq I, Dhillon HK, Bingham C, Edghill EL, Shroff R, Stanescu H, Ryffel GU, Ellard S, Bockenhauer D: Hnflb mutations associate with hypomagnesemia and renal magnesium wasting. J Am Soc Nephrol 2009;20:1123-1131.

2 Faguer S, Chassaing N, Bandin F, Prouheze C, Garnier A, Casemayou A, Huart A, Schanstra JP, Calvas P, Decramer S, Chauveau D: The HNF1B score is a simple tool to select patients for HNF1B gene analysis. Kidney Int 2014;86: $1007-1015$ 
3 Ferrè S, de Baaij JH, Ferreira P, Germann R, de Klerk JB, Lavrijsen M, van Zeeland F, Venselaar H, Kluijtmans LA, Hoenderop JG, Bindels RJ: Mutations in PCBD1 cause hypomagnesemia and renal magnesium wasting. J Am Soc Nephrol 2014;25:574-586.

4 Vivante A, Kohl S, Hwang DY, Dworschak GC, Hildebrandt F: Single-gene causes of congenital anomalies of the kidney and urinary tract (CAKUT) in humans. Pediatr Nephrol 2014;29:695-704.

5 de Baaij JH, Hoenderop JG, Bindels RJ: Magnesium in man: implications for health and disease. Physiol Rev 2015;95:1-46.

6 de Baaij JH, Dorresteijn EM, Hennekam EA, Kamsteeg EJ, Meijer R, Dahan K, Muller M, van den Dorpel MA, Bindels RJ, Hoenderop JG, Devuyst O, Knoers NV: Recurrent FXYD2 p.Gly41Arg mutation in patients with isolated dominant hypomagnesaemia. Nephrol Dial Transplant 2015;30:952-957.

7 Ferrè S, Veenstra GJ, Bouwmeester R, Hoenderop JG, Bindels RJ: HNF-1B specifically regulates the transcription of the $\gamma$ a-subunit of the NA+/K+-ATPase. Biochem Biophys Res Commun 2011;404:284-290.

8 Raaijmakers A, Corveleyn A, Devriendt $\mathrm{K}$, van Tienoven TP, Allegaert K, Van Dyck $M$, van den Heuvel L, Kuypers D, Claes K, Mekahli D, Levtchenko E: Criteria for HNF1B analysis in patients with congenital abnor- malities of kidney and urinary tract. Nephrol Dial Transplant 2015;30:835-842.

9 Chauveau D, Faguer S, Bandin F, Guigonis V, Chassaing N, Decramer S: HNF1B: paradigme d'un gène du développement et émergence inattendue d'une nouvelle maladie génétique rénale. Nephrol Ther 2013;9:393397.

10 Rebouissou S, Vasiliu V, Thomas C, Bellanné-Chantelot $\mathrm{C}$, Bui $\mathrm{H}$, Chrétien $\mathrm{Y}$, Timsit J, Rosty C, Laurent-Puig P, Chauveau D, Zucman-Rossi J: Germline hepatocyte nuclear factor 1alpha and lbeta mutations in renal cell carcinomas. Hum Mol Genet 2005;14: 603-614.

11 Heidet L, Decramer S, Pawtowski A, Morinière $\mathrm{V}$, Bandin $\mathrm{F}$, Knebelmann B, Lebre AS, Faguer S, Guigonis V, Antignac C, Salomon R: Spectrum of HNF1B mutations in a large cohort of patients who harbor renal diseases. Clin J Am Soc Nephrol 2010;5:10791090.

12 Faguer S, Decramer S, Chassaing N, BellannéChantelot C, Calvas P, Beaufils S, Bessenay L, Lengelé JP, Dahan K, Ronco P, Devuyst O, Chauveau D: Diagnosis, management, and prognosis of HNF1B nephropathy in adulthood. Kidney Int 2011;80:768-776.

13 Chen YZ, Gao Q, Zhao XZ, Chen YZ, Bennett CL, Xiong XS, Mei CL, Shi YQ, Chen XM: Systematic review of TCF2 anomalies in renal cysts and diabetes syndrome/maturity onset diabetes of the young type 5. Chin Med J (Engl) 2010;123:3326-3333.

14 Clissold RL, Hamilton AJ, Hattersley AT, Ellard S, Bingham C: HNF1B-associated renal and extra-renal disease-an expanding clinical spectrum. Nat Rev Nephrol 2015;11:102-112.

15 Roelandt P, Antoniou A, Libbrecht L, Van Steenbergen W, Laleman W, Verslype C, Van der Merwe S, Nevens F, De Vos R, Fischer E, Pontoglio $M$, Lemaigre $F$, Cassiman $D$ : HNF1B deficiency causes ciliary defects in human cholangiocytes. Hepatology 2012;56: 1178-1181.

16 Kasperavičiūtè D, Catarino $\mathrm{CB}$, Chinthapalli K, Clayton LM, Thom M, Martinian L, Cohen $\mathrm{H}$, Adalat S, Bockenhauer D, Pope SA, Lench N, Koltzenburg M, Duncan JS, Hammond P, Hennekam RC, Land JM, Sisodiya SM: Uncovering genomic causes of co-morbidity in epilepsy: gene-driven phenotypic characterization of rare microdeletions. PLoS One 2011;6:e23182.

17 Laffargue F, Bourthoumieu S, Llanas B, Baudouin V, Lahoche A, Morin D, Bessenay L, De Parscau L, Cloarec S, Delrue MA, Taupiac E, Dizier E, Laroche C, Bahans C, Yardin C, Lacombe D, Guigonis V: Towards a new point of view on the phenotype of patients with a $17 q 12$ microdeletion syndrome. Arch Dis Child 2015;100:259-264. 